\title{
Effect of oral salbutamol and slow-release aminophylline on exercise tolerance in chronic bronchitis
}

\author{
AG LEITCH, A MORGAN, DA Ellis, G BELL, C HASLETT, GJR MchARDY \\ From the Department of Respiratory Medicine, University of Edinburgh, City Hospital, Edinburgh
}

ABSTRACT In a double-blind placebo-controlled trial in 24 patients fulfilling the MRC criteria for chronic bronchitis, oral salbutamol $4 \mathrm{mg}$ and slow-release aminophylline (Phyllocontin) $450 \mathrm{mg}$ produced similar and significant $(p<0.05)$ mean increases in forced expiratory volume in one second $\left(F E V_{1}\right)$. A significantly greater increase in mean $F_{1} V_{1}$ and forced vital capacity (FVC) was seen when both drugs were given although there was no statistical evidence of synergistic interaction. Salbutamol significantly increased the mean distance walked in 12 minutes (12MD) (p< $0.02)$ by 56 metres and a similar increase of 54 metres $(p<0.001)$ was seen after Phyllocontin. With both drugs in combination mean 12MD increased by 51 metres ( $p<0.02$ cf placebo), a change not significantly different from that observed with either drug alone. Oral salbutamol and Phyllocontin improve exercise tolerance in chronic bronchitis. The significantly greater changes in $\mathrm{FEV}_{1}$ and FVC resulting from simultaneous administration of the two drugs are not associated with further improvement in exercise tolerance.

We have previously shown the value of the 12-minute walking distance (12MD) in assessing exercise tolerance in dyspnoeic patients ${ }^{1}$ and have used this test to assess the effect of aerosol bronchodilators on exercise tolerance in patients with chronic bronchitis. $^{2}$

There are good theoretical reasons for anticipating a beneficial interaction between theophyllines and $\beta$ adrenergic agents in airways obstruction, ${ }^{3}$ and such an interaction has been demonstrated in asthmatic patients. ${ }^{4}$ We have therefore compared the effects of a $\beta$-adrenergic agent, salbutamol, and a theophylline, Phyllocontin (slow-release aminophylline), given singly and in combination by the oral route, on $\mathrm{FEV}_{1}, \mathrm{FVC}$, and $12 \mathrm{MD}$ in a double-blind controlled study to see if a similar interaction occurs in chronic bronchitic patients.

\section{Patients and methods}

We studied 24 patients who fulfilled the Medical Research Council criteria for chronic bronchitis ${ }^{5}$ (table 1). All had been or were heavy cigarette smokers, none had peripheral blood eosinophilia,

Address for reprint requests: Dr AG Leitch, Department of Respiratory Medicine, City Hospital, Greenbank Drive, Edinburgh EH10 5SB.
Table 1 Characteristics of the 24 patients studied (19 men and five women)

\begin{tabular}{lrr}
\hline & Mean & \multicolumn{1}{c}{ Range } \\
\hline Age (yr) & 62 & $42-74$ \\
Height (cm) & 164 & $152-178$ \\
Weight (kg) & 65 & $35-90$ \\
FEV (ml) & 807 & $200-1900$ \\
FVC (ml) & 2223 & $700-3860$ \\
l2MD (metres)* $^{*}$ & 897 & $413-1250$ \\
\hline
\end{tabular}

* Measured on day 1 of study

and patients with positive skin tests to common allergens were excluded. Patients who had angina, intermittent claudication or a locomotor disorder were also excluded. Bronchodilator agents were withheld for 12 hours before the studies. We measured $\mathrm{FEV}_{1}$ and $\mathrm{FVC}$ on a low resistance spirometer, ${ }^{6}$ taking the best of three readings, ${ }^{7}$ and we also measured the 12MD. ${ }^{1}$

We studied the patients on five consecutive days. On the first day we measured 12MD on two occasions to accustom the patient to the test and to exclude early training effects. ${ }^{1}$ The Latin-Square design of the trial allowed for within-study training effects. On each of the other four days the patients received, on a double-blind basis, one of the four following treatments, according to a Latin-Square 
design: (a) placebo + placebo; (b) Phyllocontin 450 $\mathrm{mg}+$ placebo; (c) placebo + salbutamol $4 \mathrm{mg}$; (d) salbutamol $4 \mathrm{mg}+$ Phyllocontin $450 \mathrm{mg}$.

We measured $\mathrm{FEV}_{1}, \mathrm{FVC}$, and 12MD before and three hours after each treatment. We calculated analyses of variance that used the Latin-Square design of the trial thus enabling unbiased comparisons between treatments to be made. These analyses are briefly summarised in table 2 and the results of significance tests among the treatment means are indicated by asterisks.

We also calculated correlation coefficients for $12 \mathrm{MD}$ with $\mathrm{FEV}_{1}$ and FVC.

\section{Results}

The results are summarised in table 2 . There were no significant differences at the $5 \%$ level between the baseline values for $\mathrm{FEV}_{1}, \mathrm{FVC}$, and 12MD before each treatment.

For both $\mathrm{FEV}_{1}$ and FVC the mean increase after treatment was greater after all active treatments than after placebo. For each comparison with the placebo the $t$ statistic was significant except for change in FVC after Phyllocontin alone (table 2). The mean increases in both FEV 1 and FVC after the combined active treatment were significantly greater than those seen after either single active treatment $(p<0.001)$. The mean changes in 12MD after all three active treatments were similar and significantly greater than that after placebo $(p<0.02)$, but the differences between the combined and single active treatments were not significant.

Of the measurements made before treatments with placebo 12MD correlated better with FVC ( $\mathrm{r}=$ 0.5981) than with $\mathrm{FEV}_{1}(\mathrm{r}=0.4723)$.

\section{Discussion}

The changes in $\mathrm{FEV}_{1}, \mathrm{FVC}$, and 12MD after drugs were recorded at a time when the serum levels and bronchodilator effects of both drugs were likely to have reached a maximum. ${ }^{8}{ }^{9}$ The doses used were chosen on the basis of previous work showing maximum bronchodilatation at these doses without side-effects. With these standard doses we have demonstrated significant increases in $\mathrm{FEV}_{1}$ and, for the first time, significant increases in $12 \mathrm{MD}$ in patients with chronic bronchitis after oral bronchodilator therapy with either salbutamol or Phyllocontin. Combination of the two active agents produced significantly greater increases in $\mathrm{FEV}_{1}$ and FVC than with either agent alone. Nevertheless, this further bronchodilatation was not associated with any further improvement in 12MD.

We have now demonstrated similar improvements in 12MD after aerosol ${ }^{2}$ and oral bronchodilator therapy in patients with chronic bronchitis. In neither study do our results suggest a close correlation between changes in $\mathrm{FEV}_{1}$ and 12MD. This could be related to poor physical fitness in our patients. This would restrict their ability to benefit maximally in terms of exercise tolerance from the acute improvements in airways obstruction produced by the bronchodilator medications. Such a hypothesis is open to testing in chronic bronchitic patients who have been trained. ${ }^{10-12}$

We conclude that oral salbutamol and Phyllocontin in conventional dosage improve exercise tolerance in chronic bronchitis. Simultaneous administration of the drugs is not associated with any further improvement in exercise tolerance.

We are grateful to Messrs Allen and Hanburys and Messrs NAPP for providing active and placebo drugs, to Mrs MV Shotter for statistical advice, and to Mrs R Haldane for secretarial help.

\section{References}

${ }^{1}$ McGavin CR, Gupta SP, McHardy GJR. Twelve minute walking test for assessing disability in chronic bronchitis. Br Med J 1976;1:822-3.

Table 2 Mean values $\pm S E M$ for $F E V_{1}, F V C$, and $12 M D$ in 24 patients before treatment and the mean values for changes after treatment

\begin{tabular}{lllllll}
\hline Treatment & $\begin{array}{l}\text { I2MD before } \\
(\text { metres })\end{array}$ & $\begin{array}{l}\text { Change in 12MD } \\
(\text { metres }) \\
(\text { mean }+(\text { range) }\end{array}$ & $\begin{array}{l}F E V_{1} \text { before } \\
(\mathrm{ml})\end{array}$ & $\begin{array}{l}\text { Change in FEV } \\
(\mathrm{ml})\end{array}$ & $\begin{array}{l}\text { FVC before } \\
(\mathrm{ml})\end{array}$ & $\begin{array}{l}\text { Change in FVC } \\
(\mathrm{ml})\end{array}$ \\
\hline $\begin{array}{l}\text { Double placebo } \\
\text { Phyllocontin } \\
\quad+\text { placebo }\end{array}$ & $936 \pm 49$ & $+3(-150-+110)$ & $832 \pm 95$ & -28 & $2300 \pm 169+38$ \\
$\begin{array}{l}\text { Placebo } \\
\quad+\text { salbutamol }\end{array}$ & $923 \pm 48$ & $+54(-25-+147)^{* * *}$ & $832 \pm 88$ & $+48^{*}$ & $2388 \pm 155$ & +62 \\
$\begin{array}{l}\text { Phyllocontin } \\
+ \text { salbutamol }\end{array}$ & $925 \pm 47$ & $+56(-20-+260)^{* *}$ & $858 \pm 104$ & $+69 * *$ & $2326 \pm 153$ & $+179^{*}$ \\
\hline
\end{tabular}

Changes after active treatments compared with the changes after placebo. The results of the significance tests are: ${ }^{*} p<0 \cdot 05 ;{ }^{*} p<0 \cdot 02$; $* * * p<0.001$. 
${ }^{2}$ Leitch AG, Hopkin JM, Ellis DA, Merchant S, McHardy GJR. The effect of aerosol ipratropium bromide and salbutamol on exercise tolerance in chronic bronchitis. Thorax 1978;33:711-3.

${ }^{3}$ Campbell IA, Middleton WG, McHardy GJR, Shotter MV, McKenzie R, Kay AB. Interaction between isoprenaline and aminophylline in asthma. Thorax 1977; $32: 424-8$

4 Wolfe JD, Tashkin DP, Calvarese B, Simmons $M$. Bronchodilator effects of terbutaline and aminophylline alone and in combination in asthmatic patients. $N$ Engl $J$ Med 1978;298:363-7.

5 Medical Research Council. Definition and classification of chronic bronchitis for clinical and epidermiological purposes (Report to the Medical Research Council by their Committee on the Aetiology of Chronic Bronchitis). Lancet 1965;1:775-9.

- McKerrow CB, McDermott M, Gilson JC. A spirometer for measuring the forced expiratory volume with a simple calibrating device. Lancet 1960;1:149-51.
7 Freedman S, Prowse K. How many blows make an $\mathrm{FEV}_{1}$ ? Lancet 1966;2:618-9.

8 Boroda C, Miller RB, Leslie ST, Nicol EG, Thomson I. Comparison of the bioavailability of aminophylline in a conventional base and in a continuous-release base. $J$ Clin Pharmacol 1973;13:383-7.

- Walker SR, Evans ME, Richards AJ, Paterson JW. The clinical pharmacology of oral and inhaled salbutamol. Clin Pharmacol Ther 1972;13:861-7.

${ }^{10}$ McGavin CR, Gupta SP, Lloyd EL, McHardy GJR. Physical rehabilitation for the chronic bronchitic: Results of a controlled trial of exercises in the home. Thorax 1977;32:307-11.

${ }^{11}$ Sinclair DJM, Ingram CC. Controlled trial of supervised exercise training in chronic bronchitis. Br Med J 1980; 280:519-21.

12 Belman MJ, Mittman C. Ventilatory muscle training improves exercise capacity in chronic obstructive pulmonary disease patients. Am Rev Respir Dis 1980;121: 273-80. 